\title{
Hair chromium concentration and chromium excretion in tannery workers
}

\author{
G SANER, V YÜZBAŞIYAN, AND S ÇIGDEM \\ From the Department of Paediatrics, University of Istanbul, Çapa, Istanbul, Turkey
}

ABSTRACT Hair and urine samples were collected from 34 male tannery workers and from 12 normal adults. Eighteen of the workers dealt directly with chromium and the remaining 16 (controls) worked in the offices and kitchen of the same factory. All were found to be clinically healthy. Chromium was determined by flameless atomic absorption spectroscopy. When compared with normal adult values, urinary chromium concentration, $\mathrm{Cr} / \mathrm{Creatinine}$ ratio, daily chromium excretion, and hair chromium, concentrations were significantly higher and urinary $\beta_{2}-$ microglobulin/Cre ratios significantly lower in both tannery workers and in controls. A significant negative correlation was found between urinary $\beta_{2}$-microglobulin/Cre and $\mathrm{Cr} / \mathrm{Cre}$ ratios of tannery workers and controls. A significant positive correlation was shown between hair chromium and urinary $\mathrm{Cr} / \mathrm{Cre}$ values in all workers. No correlations between the duration of exposure to chromium and hair and urinary chromium values were found. Nevertheless, high values observed in workers with short exposures show that chromium is readily absorbed through the respiratory system.

Large numbers of people working in different occupations may be exposed to chromium compounds. There is mention of nephrotoxic, hepatotoxic, and cardiotoxic effects of chromates in people in early publications. ${ }^{2}$ More recent reports have given a more detailed picture of the toxicity of chromium in people. Hexavalent chromium may cause skin ulceration, acute irritative dermatitis, allergic eczematous dermatitis, allergic asthmatic reactions, ulcerations in the mucous membranes, and perforation of the nasal septum. Chronic exposure to chromium compounds can also cause cancer in the respiratory organs and in the gastrointestinal tract. ${ }^{34}$ In addition, necropsy has shown renal tubular necrosis in a fatal case of dichromate ingestion. ${ }^{5}$ Animal experiments also indicate that chromates selectively produce proximal tubular damage ${ }^{67}$ Gylseth et al found a high degree of correlation between inhaled chromium and urinary chromium concentration. ${ }^{8}$ The results of experimental studies have also indicated that after inhalation of water soluble chromates, the urine is the major route of chromium excretion. 9 Therefore, urinary chromium determination seems to be the most reliable biological

Received 22 December 1982

Accepted 14 March 1983 index of chromate exposure. Hair chromium determination is another method suggested for the direct assessment of chromium nutrition, and this method has also been applied widely for detecting deficiency and excess of chromium in the body. ${ }^{10}$

Bichromates are widely used in dyeing and in the quick method of tanning leather. Tannery workers may thus be exposed to undue amounts of chromium. Health problems related to excess of chromium, hair chromium concentrations, and urinary chromium excretion were investigated in tannery workers in the present study.

\section{Material and methods}

The study was carried out on 12 normal adults and 34 male tannery workers aged 19-62. Eighteen of the workers dealt directly with chromium; the remaining 16 (the control group) worked in the offices and kitchen of the same factory. The normal adults consisted of staff and medical students aged 21-30 who were in apparent good health and had no overt signs of metabolic, gastrointestinal, or respiratory disease. All workers were given a clinical examination and routine urine analysis was performed. Age, smoking habits, and employment histories were noted. Twenty four hour urine samples were collected in polyethylene bottles and volumes 
were recorded. The samples were kept at $-20^{\circ} \mathrm{C}$ until the time of analysis. All equipment used in the collection procedure was checked for chromium contamination before use.

Hair samples were taken from the suboccipital area of the head immediately next to the scalp and stored in plastic bags. None of the subjects used any hair shampoo or colouring substance before the collection of hair samples.

Chromium content of hair was determined by the flameless atomic absorption technique using a Perkin-Elmer 503 double-beam atomic absorption spectrometer equipped with both an HGA-2100 graphite furnace and a model 56 recorder. ${ }^{11}{ }^{12}$ The validity of analytical methods was verified by the use of NBS Brewer's yeast, certified for chromium.

Since the above system lacks the capacity to correct for background signals in the analysis of urine samples, urinary chromium determinations were performed at the Human Nutrition Center, Nutrition Institute, USDA, Beltsville, Md, USA.$^{13}$ Urine samples were placed in metal free sterile polypropylene tubes with snap caps, sealed by wrapping parafilm around the caps, and placed in self sealing plastic bags. The samples were transported by air to the analytical laboratory. Prior analysis of the interlaboratory urine standards transported in the same manner had shown that such transport did not alter the urinary chromium concentration.

Urinary creatinine concentrations were determined by the Jaffé reaction ${ }^{14}$ and $\beta_{2}$-microglobulin concentration by radioimmunoassay (Phadebas $\boldsymbol{\beta}_{\mathbf{2}}$-microtest Pharmacia Diagnostics, Uppsala, Sweden).

\section{Results}

The atmospheric concentration of chromium or chromate was not measured in this factory.
Nevertheless, the absence of special ventilation facilities was noted. Therefore, the chromate-dust concentration in air may be high in this working area. The duration of employment of the workers ranged from one month to 30 years with a workday of eight hours; 10 of the 34 workers had an exposure time of two years or less, and 13 were exposed for more than five years. None of the workers showed clinical evidence of metabolic, gastrointestinal, or respiratory disease, or allergic reactions and skin alterations. Only one subject had a minimal albuminuria in routine urine analysis.

Table 1 shows urinary chromium excretion and $\beta_{2}$-microglobulin/creatinine ratios in the tannery workers, controls, and normal adults. As seen in the table, mean urinary chromium concentration, $\mathrm{Cr} /$ Cre ratio, and daily chromium excretion were significantly higher in tannery workers compared with the control group. Higher values for urinary chromium concentration, $\mathrm{Cr} / \mathrm{Cre}$ ratio, and daily chromium excretion were also observed in the tannery workers and the controls when compared with the healthy normal adult values. Daily urine volumes and urine creatinine values did not differ significantly between groups. Although the urine $\boldsymbol{\beta}_{2}$-microglobulin concentrations were within normal limits in each group, the $\boldsymbol{\beta}_{2}$-microglobulin/creatinine ratios of tannery workers and controls were significantly lower than the values found in normal adults. A significant negative correlation was found between urinary $\beta_{2}$-microglobulin/Cre and urinary $\mathrm{Cr} / \mathrm{Cre}$ ratios of both the tannery workers and the controls $(\mathrm{r}=-0.53, t=2.83, \mathrm{p}<0.02)$.

Table 2 shows hair chromium concentrations in the tannery workers, controls, and normal adults. No significant difference in hair chromium concentrations was observed between the tannery workers and controls. In three workers who deal directly with chromium the concentration was extremely

Table 1 Urinary chromium excretion and $\beta_{2}$-microglobulin/creatinine ratios in tannery workers, controls, and normal subjects (mean $\pm S E M)$

\begin{tabular}{|c|c|c|c|c|}
\hline \multirow[t]{2}{*}{ Groups } & \multicolumn{4}{|l|}{ Urine } \\
\hline & $\begin{array}{l}\text { Cr conc } \\
(\mathrm{ng} / \mathrm{ml})\end{array}$ & $\begin{array}{l}\text { Cr/Cre ratio } \\
\text { (ng/mg) }\end{array}$ & 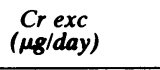 & $\begin{array}{l}\beta_{2} \text { microglobulin/Cre ratio } \\
\left(\mu \mathrm{g} \beta_{z} / \mathrm{mg} \text { Cre } \times 10^{3}\right)\end{array}$ \\
\hline $\begin{array}{l}\text { Tannery workers }(n=18) \\
\text { (dealing directly with chromium) }\end{array}$ & $6.6 \pm 1.2$ & $5 \cdot 6 \pm 1 \cdot 0$ & $9 \cdot 3 \pm 1 \cdot 8$ & $92 \pm 18(15)$ \\
\hline $\begin{array}{l}\text { Controls ( } n=16 \text { ) (working in the } \\
\text { offices and kitchen of the same } \\
\text { factory) }\end{array}$ & $2 \cdot 3 \pm 0.5$ & $1.9 \pm 0.3$ & $2 \cdot 8 \pm 0.5$ & $97 \pm 18(10)$ \\
\hline Normal adults $(n=12)$ & $0.22 \pm 0.03$ & $0.26 \pm 0.04$ & $0.31 \pm 0.04$ & $153 \pm 8(8)$ \\
\hline
\end{tabular}

Urinary Cr conc: tannery workers $v$ controls, $t=3 \cdot 2426, \mathrm{p}<0.01$; tannery workers $v$ normals, $t=4.3763, \mathrm{p}<0.001$; controls $v$ normals, $t=$ 3.7724, $\mathrm{p}<0.001$.

Cr/Cre ratio: tannery workers $v$ controls, $t=3.3408, \mathrm{p}<0.01$; tannery workers $v$ normals, $t=4.2665, \mathrm{p}<0.001$; controls $v$ normals, $t=$ $4.7388, \mathrm{p}<0.001$.

Daily Cr exc: tannery workers $v$ controls, $t=3.1654, \mathrm{p}<0.01$; tannery workers $v$ normals, $t=3.9245, \mathrm{p}<0.001$; controls $v$ normals, $t=$ 4.1637, $\mathrm{p}<0.001$.

$\beta_{2}$-microglobulin/Cre ratio: tannery workers $v$ normals, $t=2.4268, \mathrm{p}<0.05$; controls $v$ normals, $t=2.6031, \mathrm{p}<0.02$. 
Table 2 Hair chromium concentrations in tannery workers, controls, and normal adults (mean $\pm S E M$ )

\begin{tabular}{ll}
\hline Groups & $\begin{array}{l}\text { Hair chromium } \\
\text { concentration }(\mu \mathrm{g} / \mathrm{g})\end{array}$ \\
\hline $\begin{array}{l}\text { Tannery workers }(\mathrm{n}=17) \\
\text { (dealt directly with chromium) }\end{array}$ & $17.4 \pm 3.6$ \\
$\begin{array}{l}\text { Controls ( }=13) \\
\text { (worked in the offices and kitchen } \\
\text { of the same factory) }\end{array}$ & $14 \cdot 5 \pm 2.9$ \\
Normal adults ( $=11)$ & $0.559 \pm 0.071$ \\
\hline
\end{tabular}

Hair $\mathrm{Cr}$ Conc: tannery workers $v$ normals, $t=3.7414, \mathrm{p}<0.001$; controls $v$ normals, $t=4.4557, \mathrm{p}<0.001$.

high with values of $54.9 \mu \mathrm{g} / \mathrm{g}$, and $49.7 \mu \mathrm{g} / \mathrm{g}$, and $37.2 \mu \mathrm{g} / \mathrm{g}$. Mean hair chromium concentrations for tannery workers and controls were found to be significantly higher than those in normal adults. A significant positive correlation was found between hair chromium concentrations and $\mathrm{Cr} / \mathrm{Cre}$ ratios in urine in the tannery workers $(\mathrm{r}=0.48, t=2 \cdot 51, \mathrm{p}=$ $0.02)$. Urinary chromium excretion and hair chromium concentrations were not significantly correlated with the duration of chromium exposure.

\section{Discussion}

This investigation has shown that the urinary excretion of chromium is greatly increased in tannery workers dealing directly with chromium as well as in office and kitchen workers of the same factory. The findings indicate that tannery workers, including those not dealing directly with chromium compounds, have a significant exposure to chromium. Although the atmospheric chromium concentrations in the different regions of the factory are not known, significant amounts must be diffusing into the air and be absorbed through the respiratory system. The presence of high hair chromium concentrations in both groups of workers shows clearly the absorption of environmental chromium and points to the possibility of overaccumulation under certain conditions. The significant positive correlation found between hair chromium concentrations and urinary chromium/creatinine ratios in these workers further shows that urinary chromium excretion can be used as an indicator of chromium exposure. The urinary excretion of chromium shortly after exposure to chromates has been reported to reflect accurately the dose. ${ }^{15}$

To investigate the possible nephrotoxic effects of chromium urinary $\beta_{2}$-microglobulin concentrations were determined in the two groups of workers and in normal adults. A pronounced rise in the urinary excretion of $\beta_{2}$-microglobulin may indicate proximal tubular damage. ${ }^{16}$ Unexpectedly, the $\beta_{2}$ microglobulin/creatinine ratios of tannery workers and controls were found to be significantly lower than in the normal adults. Additionally, a significant negative correlation between the $\beta_{2}$-microglobulin/ creatinine and $\mathrm{Cr} / \mathrm{Cre}$ ratios was observed in these workers. The low $\beta_{2}$-microglobulin/Cre ratios in tannery workers and in controls are hard to account for. We can speculate only that impaired synthesis or a decreased turnover of $\beta_{2}$-microglobulin, or both, may be present in these workers and point to the need for further studies to explain these findings.

No correlations between the duration of exposure to chromium and hair and urinary chromium values were found. Values as high as $12.6 \mu \mathrm{g} /$ day and 12.5 $\mu \mathrm{g} /$ day, however, were observed for urinary chromium excretion in two workers dealing directly with chromium compounds who had started the job only one month previously. Their hair chromium concentrations were $12.6 \mu \mathrm{g} / \mathrm{g}$ and $4.4 \mu \mathrm{g} / \mathrm{g}$ respectively. Urinary chromium excretion rates of 2.32 $\mu \mathrm{g} /$ day and $1.2 \mu \mathrm{g} /$ day were observed in office workers with a history of one and three months at the job, the hair chromium value of the latter being $2.4 \mu \mathrm{g} / \mathrm{g}$. Such high values observed in workers with short exposures shows that chromium is readily absorbed through the respiratory system. No clinical manifestations of exposure to chromium, however, were found in the workers who had been employed in same factory for 18 to 30 years.

We are indebted to Drs W Mertz, R Andersen, and W Wolf, Human Nutrition Center, USDA, Beltsville, Md, for the determination of chromium in urine samples.

Supported in part by funds from the Turkish Scientific and Technical Research Council.

\section{References}

${ }^{1}$ Brieger H. Zur Klinik der Akuten Chromatvergiftung. Z Exp Pathol Ther 1920;21:393-408.

${ }^{2}$ Goldman M, Karotin RH. Acute potassium dichromate poisoning. Am J Med Sci 1935;189:400-3.

${ }^{3}$ Langârd S, Norseth T. Chromium. In: Friberg L, ed. Handbook on the toxicology of metals. Amsterdam: Elsevier NorthHolland, 1979:383-97.

4 Langård S. Chromium. In: Waldron HA, ed. Metals in the environment. London: Academic Press, 1980:111-33.

${ }^{5}$ Kaufman DB, DiNicola W, McIntosh R. Acute potassium dichromate poisoning. Treated by peritoneal dialysis. Am J Dis Child 1970;119:374-6.

- Schubert GE, Gebhard K, Hönlein F. Nierenschädigung nach Serotonin-und Kaliumdichromatinjektion bei chronischer Natriumbelastung oder -restriktion. Virchows Arch (Pathol Anat) 1970;351:68-82.

${ }^{7}$ Evan AP, Dail WG. The effects of sodium chromate of the proximal tubules of the rat kidney. Fine structural damage and lysozymuria. Lab Invest 1974;30:704-15. 
Bylseth B, Gundersen N, Langârd S. Evaluation of chromium exposure based on a simplified method for urinary chromium determination. Scand J Work Environ Health 1977;3:28-31.

${ }^{9}$ Langård S, Gundersen N, Tsalev DL, Gylseth B. Whole blood chromium level and chromium excretion in the rat after zinc chromate inhalation. Acta Pharmacol Toxicol 1978;42:142-9.

${ }^{10}$ Saner G. Chromium in nutrition and disease. In: Saner G, ed. Current topics in nutrition and disease. Vol 2. New York: Alan R Liss, 1980.

"Wolf WR, Greene E. Preparation of biological materials for chromium analysis. In: LaFleur PD, ed. Accuracy in trace analysis: sampling, sample handling, analysis I. Washington, DC: Government Printing Office, 1976:605-10.

${ }^{12}$ Saner G. The effect of parity on maternal hair chromium con- centration and the changes during pregnancy. Am J Clin Nutr 1981;34:853-5.

${ }^{13}$ Guthrie BE, Wolf WR, Veillon C. Background correction and related problems in the determination of chromium in urine by graphite furnace atomic absorption spectrometry. Anal Chem 1978;50:1900-2.

14 Bonsnes RW, Taussky HH. On the colorimetric determination of creatinine by the Jaffé reaction. J Biol Chem 1945;158:58191.

${ }^{15}$ Collins RJ, Fromm PO, Collings WD. Chromium excretion in the dog. Am J Physiol 1961;201:795-8.

${ }^{16}$ Roels H, Bernard A, Buchet JP, Lauwerys R, Masson P. Urinary excretion of $\beta_{2}$-microglobulin and other proteins in workers exposed to cadmium, lead or mercury. Pathol Biol 1978;26:329-31. 